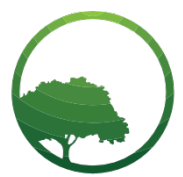

Research in Business \& Social Science

IJRBS VOL 8 NO 5 ISSN: 2147-4478

\title{
Effect of leverage and firm size on financial performance of deposit taking savings and credit cooperatives in Kenya
}

\author{
Robert Shibutse ${ }^{a^{*}}$, Elizabeth Kalunda ${ }^{b}$, George Achoki ${ }^{c}$ \\ ${ }^{a, b, c}$ Chandaria School of Business, United States International University, P.O. Box 14634 - 00800, Nairobi, Kenya
}

Crossref

\begin{tabular}{l} 
A R T I C L E IN F O \\
\hline Article history: \\
Received 31 July 19 \\
Received in revs. form 15 August 19 \\
Accepted 16 August 19 \\
\hline Keywords: \\
Capital Structure \\
Financial Performance \\
Leverage \\
Firm Size \\
JEL Classification: \\
O15 \\
P36
\end{tabular}

\section{Introduction}

A savings and credit cooperative society (SACCO) as per the International Cooperative Alliance is a financial organization formal in nature, owned, controlled, used, and democratically directed by members themselves to address the prevailing economic, social, and cultural needs (International Cooperative Alliance (ICA), 2016). Savings and Credit Cooperatives/Credit Unions represent one of the most important sources of financing in developing countries and in the last few years, have experienced tremendous growth all over the world (Labie \& Périlleux, 2008). As at 2005, there were more than 42,000 SACCOs/Credit Union/Cooperative Financial Institution (CFI)/Mutual, serving about 92 countries with membership of over 157 million, penetration of $6.65 \%$, Savings of US\$ 763 Billion, Loans of US\$ 612 Billion, reserves of US\$ 91 Billion and total assets of 894 Billion (World Council of Credit Unions (WOCCU),2005). As at 2015, the statistics have significantly shifted showing tremendous growth with more than 60,000 SACCO's/Credit Union/ CFIs/ Mutual, serving about 109 countries with membership of over 223million, Penetration of $8.3 \%$, Savings of US\$ 1.5 Trillion, Loans of US\$1.2 Trillion, reserves of US\$185 Billion and total assets of 1.8 Trillion (WOCCU, 2015).

Kenya's national development blueprint and the Vision 2030, identified SACCO societies key role in deepening financial access, mobilize savings for investments in enterprises, and personal development (Mohammed, 2013). As at December 2012, the total assets in the SACCO subsector stood at Kshs 293 billion, total membership was 3 million persons, total deposits stood at Kshs 213 billion, and loans to members was at Kshs 221 billion (Ademba, 2013).In the year ended 2017, these figures grew to total assets of Kshs 442 billion, loan to members Kshs 332 billion and membership over 3.5 million (Sacco Societies Regulatory Authority, 2017). The

\footnotetext{
* Corresponding author. Tel: +254721598566 ORCID ID: 0000-0001-9311-4397
}

Peer review under responsibility of Bussecon International Academy.

(C) 2019 Bussecon International. Hosting by SSBFNET- Center for Strategic Studies in Business \& Finance. All rights reserved.

https://doi.org/10.20525/ijrbs.v8i5.462 
commissioner of cooperatives registers and supervises Non-Deposit Taking SACCOs, while Deposit-Taking SACCOs (DTSACCOs) are licensed and regulated by SASRA after having been duly registered under the Cooperative Societies Act CAP 490 by the commissioner.

According to Poulsen (2008), capital structure is the composition or construction of a firm's liabilities. Taiwo (2012) noted that capital structure is a firm's proportion of short-term and long-term debt and is principally a mix of debt and equity retained by an organization. Capital underpins cooperatives; members come together to pool money and do more together than they could alone, therefore cooperatives may get bogged down or fail to get off the ground if they cannot get enough capital either due to regulation or long-standing practice, they (Andrews, 2015). Financial performance is a measure of how well an organization employs its principal mode of business to produce revenue. It involves shaping the results of a firm's policy and operations in monetary terms based on the allocated resources to the most feasible ventures that produce returns which maximize shareholder's wealth.

The rise of free-market capitalism, the deregulation of primary industries, and increasing global competition have affected the viability of the traditional cooperative business model (Downing \& Schmidt, 2005). Hence, some governments have allowed deviations to the traditional cooperative model which have taken a variety of forms, including the acceptance of non-member owners, the appreciation, and transferability of equity and the use of proportional member control structures that is one-share-one-vote rather than one-member-one-vote. The cases of Cooperative Insurance Company (CIC) and Cooperative Bank of Kenya are unique cases where a deviation from the strict cooperative model was achieved. Hence unlike the DT-SACCOs, the study focuses on, these two organizations have overcome the inherent weaknesses of the traditional cooperative model and accommodate the dual needs of cooperative members as both patrons and investors as discussed by Chaddad and Cook (2004) and general public needs.

In the year ended 2017, there were 174 licensed DT-SACCOs in Kenya, who were required to comply with capital adequacy ratios that are core capital to total assets at 10 percent; core capital to total deposits at 8 percent and institutional capital to total assets at 8 percent (Financial Sector Regulators Forum, 2017). Of these 161 DT-SACCOs were compliant with the absolute core capital, 163 DT-SACCOs were compliant with CCD ratios, and only 146 DT-SACCOs were compliant with the CCA ratio as compared with the 173 DT-SACCOs which were compliant with the absolute core capital (Sacco Societies Regulatory Authority, 2017). This variance in the comparative level of compliance with the capital adequacy measurements shows that most DT-SACCOs found it easy to meet both the absolute core capital and the CCD ratio, but found it very hard to achieve and maintain the CCA ratio, which then results in an exposure of a substantial portion of their asset base. This demonstrates that DT-SACCOs are relatively low in the retention of their surpluses to build their capital bases but are very quick to lend to their members and build other assets, without proportionate mobilization of deposits (savings) or capital funding plan. The number of DT-SACCOs meeting the absolute core capital ratio had dropped from 173 in 2015 to 161 in 2017. Further external borrowing rose from KSh 17.82 billion in 2016 to KSh 20.1 billion in 2017, a 12.9 percent growth (Financial Sector Regulators Forum, 2017). This situation could also be because, as the business grows, expansion opportunities can arise that outstrip the financial ability of the DT-SACCO reliant on members' shares and internally generated capital.

There are several factors, both qualitative and quantitative, including subjective judgment, of organizations management, which together determine a firm's capital structure. According to Shawal (nd), factors such as profitability, liquidity, control, competitive parity, nature of the industry, the timing of issue and characteristics determine an organizations capital structure. Tittman and Wessels (1988) noted that asset structure, non-debt tax shields, growth, uniqueness, industry classification, size, earnings volatility, and profitability, are attributes that different theories of the capital structure suggest may affect the firm's debt-equity choice and therefore are determinants of capital structure. Bauer (2004) noted that several capital structure theory models surveyed had identified many potential determinants of capital structure, but empirical evidence has so far not sorted out which of these are essential in various contexts.

Capital structure is certainly central to the success of every organization, including DT-SACCOs as it to a large extent, influences the realization of its objectives and goals. Management of organizations particularly those involved in the finance function has a responsibility of determining the optimal mix of debt and equity that will ensure maximization of shareholders wealth and the immediate way of measuring the quality of any financing decision is to examine its effect on firm's performance (Njeri \& Kagiri, 2015).

In recent years, the SACCO sector has faced tough challenges globally; mission drifts, income generation, compliance, competition, and insufficient capital, among many others (WOCCU, 2012). Wasike (2012) study on factors affecting the performance of SACCOs and indicated that capital inadequacy, poor asset quality, reduced liquidity, and non-compliance were the key factors affecting SACCOs. Amedeo, Espenlaub, Khurshed, and Simkovic (2010) observed that some cooperatives in Kenya were finding it challenging to operate mainly because of their poor financial state. Mvula (2013) presented a report on common issues affecting the performance of SACCOs and pointed out that the problems affecting the performance of SACCOs are inadequate capital, poor asset quality, poor governance, reduced profitability, poor liquidity, and non-compliance. In last several years, we have seen increased concern from the regulator on DT-SACCO financial management, mainly reflecting on Capital management in the institutions which could potentially impact on institutional performance (Anyanzwa, 2018; Marete, 2016; Wanzala, 2019; Munaita, 2018). 
Several studies have been carried out on capital structure and financial performance of organizations, these have been limited by; geographic scope, industry, firm biases. So far and to the best of my knowledge, none has covered all the licensed DT-SACCOs in Kenya except Mwatu and Abdul (2018) study which utilized debt, equity, and liquidity as capital structure determinants. This study focused on selected capital structure determinants specifically, leverage and firm size and their effects on the financial performance of DT-SACCOs in Kenya giving the significance of each determinant and whether it has a positive or negative effect on performance. The study's population is the 174 licensed SACCOs in the Country that were registered as at 2017.

The general objective of the study was to establish the effects of capital structures determinants on the financial performance of DTSACCOs in Kenya.

The specific objectives of the study were:

i. To determine how leverage affects the financial performance of DT-SACCOs in Kenya.

ii. To assess the effect of firm size on the financial performance of DT-SACCOs in Kenya.

iii. To assess the combined effect of leverage and firm size on the financial performance of DT-SACCOs in Kenya.

The hypotheses tested in the study were as follows:

$\mathrm{H}_{0} 1$ There is no significant effect of leverage on the financial performance of DT-SACCOs in Kenya.

$\mathrm{H}_{0} 2$ Firms size does not significantly affect the financial performance of DT-SACCOs in Kenya.

$\mathrm{H}_{0} 3$ There is no significant effect of combined determinants of capital structure; leverage and firm size on the financial performance of DT-SACCOs in Kenya.

\section{Literature Review}

\section{Trade-off theory}

The classical version of the hypothesis can be traced to Kraus and Litzenberger (1973), the theory postulates that the ratio of debt to equity financing is determined by balancing the costs and benefits that is a balance between the dead-weight costs of bankruptcy and the tax-saving benefits of debt. Trade-off theory suggests that companies are partly financed by debt and partly by equity, whereas the choice is made based on cost-benefit analysis. According to this theory, the trade-off between benefits of debt that is the interest tax shields and the costs of debt that is the financial distress and agency costs results in an optimal capital structure (Brigham \& Houston 2004). What the static trade-off theory suggests is that companies chose a target debt/equity ratio then move towards it (Xhaferi \& Xhaferi, 2015). Trade-off theory predicts that larger firms tend to be more diversified and hence, likely to be less susceptible to financial distress.

\section{The pecking order theory}

Based on the principle that financing decisions are made in such a way as to cause the least difficulty to management, the Pecking order theory (POT) is said to be a behavioral approach to capital structure (Myers \& Majluf, 1984). An organization has a specific order of preferences which it follows in making financing decisions (Myers, 1984). The POT is all about financing the companies by an order from safer too riskier; it means it gives an advantage to internal financing compared to external funding; prefer debt to convertible bonds; prefer hybrid securities compared to equity. Compared to the trade-off theory, the POT does not impose a target debt-equity ratio; for more debt is incorporated in the external financing. The hierarchy of financing firms, according to POT suggests, a portfolio of financing, does not eliminate any kind of funding, but merely provides an order to be followed.

\section{The MM capital structure theory}

The original proposition and the fundamentals of Modigliani and Miller's Theorem (1958), makes the following key assumptions: No taxes; No transaction costs; No bankruptcy costs; Equivalence in borrowing for both companies and investors; Symmetry of market information, meaning companies and investors have the same information; and No effect of debt on a company's earnings before interest and taxes (EBIT). There were various criticisms arising out of the fact that markets are inefficient, which encouraged Modigliani and Miller to issue an alteration to their first theory, which is referred to as MM2. In their revised proposition, they incorporated tax benefits as determinants of capital structure. Modigliani and Miller show that firm value and firm performance is an increasing function of leverage due to the tax-deductibility of the interest payments at the corporate level (Modigliani \& Miller, 1963).

\section{Conceptual framework}

Mugenda (2008) defines a conceptual framework as a concise description of the phenomenon under study accompanied by a graphical or visual depiction of the significant variables of the study. The relationship between the independent and dependent variables is outlined in Figure 1. 


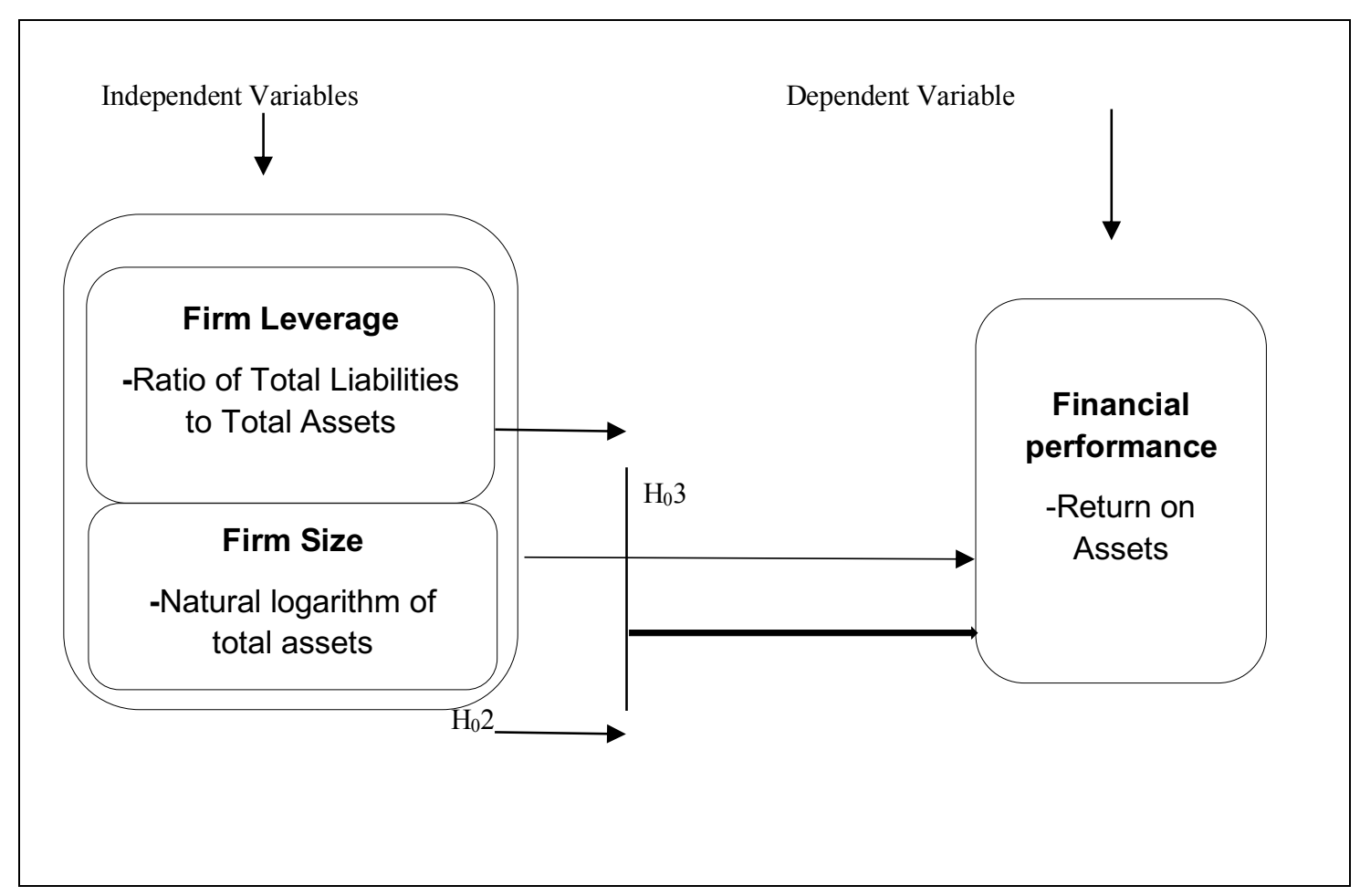

Figure 1: Conceptual framework

\section{Empirical review}

The pecking-order theory suggests that highly profitable companies tend to reduce their external funding; which at the end signals to creditors that they have low bankruptcy risk. (Sheikh \& Wang, 2011). Shubita and Alsawalhah (2012) found that there is a negative relationship between debt and profitability suggesting that the more profit a firm makes, the more they would depend on internal financing as their primary financing option. Gonzalez and Gonzalez (2012) noted that taxes, agency costs, and bankruptcy costs push more profitable firms towards higher leverage and hence a positive relationship between a firm's profitability and debt is expected in line with TOT. The higher the profitability of organizations, all factors held constant, the more the level of internal financing and therefore our expectation is a negative relationship between leverage and profitability, which is one of the most systematic findings in the empirical literature (Rajan \& Zingales, 1995). Mwatu and Abdul (2018) studied the effect of capital structure on the financial performance of DT-SACCOs in Kenya anchored on the pecking order theory. The study established that debt has a negative and statistically significant effect on the financial performance of Deposit-taking Savings and Credit Cooperative Societies in Kenya.

The trade-off theory predicts a positive relationship between the firm size and leverage because size is assumed as a proxy for earnings volatility and by Fama and French (2002) larger firms are more diversified and show less volatility. According to Singh and Kumar (2008), pecking order theory predicts a negative relationship between firm size and leverage because large firms are mostly more profitable and need more retained earnings. Kühnhausen and Stieber (2014) argued that firm size is one of the critical determinants of leverage. Gonzalez and Gonzalez (2012) studied the validity of the trade-off (TOT) and pecking order (POT) theories in explaining financing decisions vary among small, medium, and large firms. Using dynamic panel data tests in a sample of 3,439 Spanish firms over the period 1995-2003, results are partially consistent with both explanations but suggest a greater validity of pecking-order predictions for small firms. On the other hand studies such as that carried out by Mwizarubi, Kumar, Mnzava and Prutsy (2016) examining the impact of capital structure on financial performance for Savings and Credit Cooperative Societies (SACCOS, found that Firm size is found to have a negative impact on performance.

\section{Research and Methodology}

A positivist research philosophy was adopted for this study utilizing a mixed research design. Cresswell (2013) noted that mixedmethod research involves the collection, analyzing and interpreting data using both quantitative and qualitative methods offering a complete picture, hence why it is most suited for this study. The target population for this study constituted the 174 DT SACCOs licensed by SASRA in Kenya. The sample frame was obtained from the SASRAs 2017 list of licensed DT-SACCOs. 


\section{Sampling}

The study concentrated on the categorization of SACCOs into the three subgroups/strata hence use of stratified sampling. A sample of respondents was drawn from each stratum using purposive sampling, improving the representativeness of the sample.

The study used the Yamane (1967) formula for determining the sample size given by:

$\mathrm{n}=\mathrm{N} /(1+\mathrm{Ne} 2)$

Where $\mathrm{n}$, is the sample size

$\mathrm{N}$ is the population size, and e is the margin of error fixed at $5 \%$

From our target population

$\mathrm{n}=174 /(1+174(0.052))$

$\mathrm{n}=121.25$

Hence our sample size will be 122 DT-SACCOs.

\section{Data collection}

Secondary data was collected from the audited financial statements of the sampled deposit-taking SACCOs for the last five years 2013 to 2017, sourced from SASRA using data sheets. The financial information collected was Surplus/Profit after tax, Total Assets, Total fixed assets, Total debt, and Total equity. A set of structured questionnaires which incorporated Likert scales were used to collect primary data from the sampled respondents in this study. The study employed the Cronbach alpha $(\alpha)$ to test the reliability of the questionnaire with an acceptable value of 0.7 used as a cut-off in this study (Nunally, 1998). The validity of content was ascertained by ensuring that its items sufficiently cover the research objectives and subjecting to experts for judgment and peers to review the research instruments (Kothari, 2004). The respondents for the questionnaires where the senior management team in the SACCOs and members of the board or supervisory committees. The questionnaires were administered using several methods, drop and pick and electronic questionnaires followed up by a phone call to respective institutions. Ethical issues that were considered when carrying out this study were by those stated by Polit and Hungler (1999) that is, principles of beneficence, respect for human dignity, and justice. Consent was obtained for conducting the research was obtained from the necessary authorities.

\section{Data analysis}

Data was edited and coded into SPSS (Statistical Packages for Social Sciences) software in readiness for analysis. Both descriptive (a measure of central tendency and spread) and inferential data analyses ( estimates of parameters and testing of statistical hypotheses) were carried out, prior to which regression diagnostic tests for multicollinearity, heteroscedasticity, normality, and linearity were carried out to evaluate the model assumptions.

\section{Research model}

To determine the relationship that exists between the independent and dependent variables, linear regression as a statistical technique for data analysis was used (Creswell, 2013). A regression model was used to investigate the effect of determinants of capital structure on the financial performance of DT-SACCOs in Kenya as presented below;

Eq. (1) $Y i=\beta 0+\beta 1(X) i+\varepsilon$

Where: $\mathrm{Yi}=$ financial performance measured by ROA, in this case,

$\beta 0=$ the $y$-intercept (constant) for the independent variable

$\beta 1=$ regression model coefficient that is the slope which represents the degree with which the form performance changes as the independent variable changes by one unit.

$\varepsilon=$ Error term

Eq. (2) $\mathrm{Yi}=\beta 0+\beta 1(\mathrm{LEV}) i+\beta 2(\mathrm{SIZE}) i+\varepsilon$

Where: $\mathrm{Yi}=$ financial performance measured by ROA in this case

$\beta 0=$ the $y$-intercept (constant) for the independent variables

$\beta 1 \ldots . \mathrm{B} 2=$ regression model coefficient that is the slope which represents the degree with which the form performance changes as the independent variables changes by one unit.

$\mathrm{LEV}=$ leverage

$\mathrm{SIZE}=$ firm size 


\section{$\varepsilon=$ Error term}

\section{Result and Discussion}

\section{Determinants of capital structure}

In relation to the level of importance for the determinants of capital structure in the SACCOs, the mean values represent points of convergence of the different respondent's opinions regarding the importance of the determinants of capital structure. Table 1 shows that Size of SACCO in terms of total assets (mean=2.00, $\mathrm{SD}=1.13$ ) was the highest-rated determinant of capital structure (mean=1.66, $\mathrm{SD}=1.03$ ) then followed by the leverage (mean=2.42, $\mathrm{SD}=1.23$ ). The low standard deviations implied that the capital determinant responses dispersed narrowly about the mean, implying low variations in the responses given by the respondents.

Table 1: Rating on determinants of capital structure

\begin{tabular}{|c|c|c|c|c|c|c|c|c|}
\hline & $\begin{array}{l}\text { Most } \\
\text { important }\end{array}$ & $\begin{array}{l}\text { More } \\
\text { important }\end{array}$ & Important & $\begin{array}{l}\text { Less } \\
\text { important }\end{array}$ & $\begin{array}{l}\text { Least } \\
\text { important }\end{array}$ & Mean & $\begin{array}{l}\text { Std. } \\
\text { Deviation }\end{array}$ & $\begin{array}{l}\text { Total } \\
(\%)\end{array}$ \\
\hline & $\mathrm{N}$ & $\mathrm{N}$ & $\mathrm{N}$ & $\mathrm{N}$ & $\mathrm{N}$ & & & \\
\hline & $(\%)$ & $(\%)$ & $(\%)$ & $(\%)$ & $(\%)$ & & & \\
\hline Leverage & $25(25.5)$ & $34(34.7)$ & $21(21.4)$ & $9(9.2)$ & $9(9.2)$ & 2.42 & 1.23 & $\begin{array}{l}98 \\
(100)\end{array}$ \\
\hline Firm Size & $41(41.8)$ & $32(32.7)$ & $14(14.3)$ & $6(6.1)$ & $5(5.1)$ & 2.00 & 1.13 & $\begin{array}{l}98 \\
(100)\end{array}$ \\
\hline
\end{tabular}

Source: Authors compilation

\section{Impact of capital structure determinants on financial performance}

In relation to the level of impact of capital determinants on financial performance, the mean values represent points of convergence of the different respondent's opinions regarding the level of impact of the determinants of capital structure. Table 2 shows that Size of SACCO in terms of total assets has the strongest impact on financial performance (mean=1.99, $\mathrm{SD}=1.04)$ then followed by the leverage (mean=2.23, $\mathrm{SD}=1.20$ ). The low standard deviations implied that the capital determinant responses dispersed narrowly about the mean, implying low variations in the responses given by the respondents.

Table 2: Impact of capital determinants on financial performance

\begin{tabular}{lllllllll}
\hline & $\begin{array}{l}\text { Most } \\
\text { important }\end{array}$ & $\begin{array}{l}\text { More } \\
\text { important }\end{array}$ & Important & $\begin{array}{l}\text { Less } \\
\text { important }\end{array}$ & $\begin{array}{l}\text { Least } \\
\text { important }\end{array}$ & Mean & $\begin{array}{l}\text { Std. } \\
\text { Deviation }\end{array}$ & $\begin{array}{l}\text { Total } \\
(\%)\end{array}$ \\
\cline { 2 - 6 } & $\mathrm{N}$ & $\mathrm{N}$ & $\mathrm{N}$ & $\mathrm{N}$ & $\mathrm{N}$ & & & \\
\cline { 2 - 6 } & $(\%)$ & $(\%)$ & $(\%)$ & $(\%)$ & $(\%)$ & & & $\begin{array}{l}98 \\
(100)\end{array}$ \\
\hline Leverage & $32(32.7)$ & $32(32.7)$ & $21(21.4)$ & $5(5.1)$ & $8(8.2)$ & 2.23 & 1.20 & 98 \\
\hline Firm Size & $39(39.8)$ & $33(33.7)$ & $16(16.3)$ & $8(8.2)$ & $2(2.0)$ & 1.99 & 1.04 & 98
\end{tabular}

Source: Authors compilation

\section{Financial Performance of DT-SACCOS in Kenya as measured by ROA}

Descriptive statistics were used to compute the means for return on assets for each of the five years, and the results are presented graphically. The return on assets ranged from a minimum of -0.37 to a maximum of 1.00 . The average return on assets for the five years ranged from a minimum of -0.06 to a maximum of 0.08 with a standard deviation of .01864 .

Table 3: Descriptive Statistics for return on assets

\begin{tabular}{llllll}
\hline ROA & $\mathbf{N}$ & Minimum & Maximum & Mean & Std. Deviation \\
\hline $\mathbf{2 0 1 3}$ & 98 & -.02 & .11 & .0221 & .01971 \\
\hline $\mathbf{2 0 1 4}$ & 98 & -.02 & .12 & .0210 & .02105 \\
\hline $\mathbf{2 0 1 5}$ & 98 & -.37 & .20 & .0168 & .05137 \\
\hline $\mathbf{2 0 1 6}$ & 98 & -.10 & 1.00 & .0330 & .10304 \\
\hline $\mathbf{2 0 1 7}$ & 98 & -.18 & .08 & .0170 & .03687 \\
\hline Mean & 98 & -.06 & .08 & .0200 & .01864 \\
\hline
\end{tabular}

Source: Authors compilation 
The average return on assets were .0221 (2013), .0210 (2014), .0168 (2015), .0330 (2016) and .0170 (2017). ROA was highest in 2016.

\section{Leverage trend}

Descriptive statistics were used to compute the means for leverage for each of the five years, and the results are presented graphically. The leverage, as measured by the ratio of total liabilities to total assets, ranged from a minimum of 0.0 to a maximum of 2.23 . The average leverage for the five years ranged from a minimum of 0.00 to a maximum of 0.60 , with a standard deviation of 0.11326 .

Table 4: Descriptive Statistics for leverage

\begin{tabular}{llllll}
\hline Leverage & $\mathbf{N}$ & Minimum & Maximum & Mean & Std. Deviation \\
\hline $\mathbf{2 0 1 3}$ & 98 & 0.00 & .61 & .0860 & .12205 \\
\hline $\mathbf{2 0 1 4}$ & 98 & 0.00 & .73 & .0948 & .13865 \\
\hline $\mathbf{2 0 1 5}$ & 98 & 0.00 & 2.23 & .0913 & .23930 \\
\hline $\mathbf{2 0 1 6}$ & 98 & 0.00 & .67 & .0667 & .10509 \\
\hline $\mathbf{2 0 1 7}$ & 98 & 0.00 & .71 & .0651 & .11134 \\
\hline Average Leverage & 98 & 0.00 & .60 & .0825 & .11326 \\
\hline
\end{tabular}

Source: Authors compilation

The average leverage was .0860 (2013), .0948 (2014), .0913 (2015), .0667 (2016) and .0651 (2017). Leverage was highest in 2014, followed by a downward trend after that.

\section{Firm size}

Descriptive statistics were used to compute the means for firm size for each of the five years, and the results are presented graphically. The firm size, as measured by the natural logarithm of total assets, ranged from a minimum of 14.80 to a maximum of 23.94 . The average firm size for the five years ranged from a minimum of 11.62 to a maximum of 26.70 with a standard deviation of 1.97925 .

Table 5: Descriptive Statistics for firm size

\begin{tabular}{llllll}
\hline Firm size & N & Minimum & Maximum & Mean & Std. Deviation \\
\hline $\mathbf{2 0 1 3}$ & 98 & 14.80 & 23.59 & 19.7367 & 1.50191 \\
\hline $\mathbf{2 0 1 4}$ & 98 & 16.57 & 23.71 & 19.9482 & 1.40376 \\
\hline $\mathbf{2 0 1 5}$ & 98 & 15.78 & 23.74 & 20.0539 & 1.45968 \\
\hline $\mathbf{2 0 1 6}$ & 98 & 15.85 & 23.81 & 20.1299 & 1.51831 \\
\hline $\mathbf{2 0 1 7}$ & 98 & 15.68 & 23.94 & 20.2267 & 1.49466 \\
\hline Average Firm size & 98 & 11.62 & 26.70 & 20.2132 & 1.97925
\end{tabular}

Source: Authors compilation

The average firm size was 19.7367 (2013), 19.9482 (2014), 20.0539 (2015), 20.1299 (2016) and 20.2267 (2017).

\section{Effect of Leverage on Financial Performance of DT-SACCOs in Kenya.}

The results for the effect of financial leverage on the financial performance of DT-SACCOs in Kenya were assessed using the Pearson correlation coefficient, as shown in Table 6. The output indicates that financial leverage had a strong negative and significant relationship with the financial performance of DT-SACCOs in Kenya $(r=-.632, n=98, p<0.05)$.

Table 6: Correlations between leverage and financial performance

\begin{tabular}{llll}
\hline \multirow{2}{*}{ ROA } & & ROA & Leverage \\
\cline { 2 - 4 } & Pearson Correlation & 1 & $-.632^{* *}$ \\
\cline { 2 - 4 } & Sig. (2-tailed) & 900 \\
\cline { 2 - 4 } Leverage & $\mathrm{N}$ & $-.632^{* *}$ & 98 \\
\cline { 2 - 4 } & Pearson Correlation & .000 & 1 \\
\cline { 2 - 4 } & Sig. (2-tailed) & 98 & 98 \\
\hline
\end{tabular}

$* *$. Correlation is significant at the 0.01 level (2-tailed).

Source: Authors compilation 
The first objective was to determine how firm leverage affects the financial performance of DT-SACCOs in Kenya. The research hypothesis formulated from the specific research objective was;

$\mathbf{H}_{\mathbf{0}} \mathbf{1}$ There is no significant effect of leverage on the financial performance of DT-SACCOs in Kenya.

To test the above hypothesis, linear regression was used to test the relationship between leverage and financial performance of DTSACCOs in Kenya. Path coefficients were used to determine the direction and strength while $\mathrm{T}=$ statistics provided information on the significance to the relationships. The results are presented in Table 7. The $\mathrm{R}^{2}$ for the regression model between leverage and financial performance of DT-SACCOs in Kenya was 0.399 meaning that financial leverage explains $39.9 \%$ variation in the financial performance of DT-SACCOs in Kenya while the remaining variation is explained by other factors. The regression model was a good fit, as indicated by a significant $\mathrm{F}$ statistic $(\mathrm{F}=63.683, \mathrm{p}<0.05)$. The regression model obtained from the output was;

Eq. (3) $\mathrm{Yi}=0.029-0.104$ (leverage) $+\varepsilon$

The unstandardized regression coefficient for leverage was -0.104 . This indicates that a unit increase in the financial leverage would result in 0.104 decrease in the financial performance of DT-SACCOs in Kenya. The t-statistic for the regression coefficient for financial leverage was significant at $5 \%$ level of significance $(T=-7.980, p<0.05)$, implying failing to confirm the null hypothesis. By these statistics, the study concludes that there is a significant negative relationship between Financial leverage and financial performance of DT-SACCOs in Kenya.

Table 7: Effect of Leverage on Financial Performance

\begin{tabular}{|c|c|c|c|c|c|c|}
\hline \multicolumn{7}{|c|}{ Model Summary } \\
\hline \multicolumn{2}{|c|}{ Model $\quad \mathrm{R}$} & \multirow{2}{*}{$\begin{array}{l}\text { R Square } \\
.399\end{array}$} & & \multirow{2}{*}{$\begin{array}{l}\text { Adjusted R Square } \\
.393\end{array}$} & \multicolumn{2}{|c|}{ Std. Error of the Estimate } \\
\hline 1 & $.632^{\mathrm{a}}$ & & & & .01453 & \\
\hline \multicolumn{7}{|c|}{ a. Predictors: (Constant), Leverage } \\
\hline \multicolumn{7}{|c|}{ ANOVA $^{\mathrm{a}}$} \\
\hline \multicolumn{2}{|c|}{ Model } & Sum of Squares & df & Mean Square & $\mathrm{F}$ & Sig. \\
\hline \multirow[t]{3}{*}{1} & Regression & .013 & 1 & .013 & 63.683 & $.000^{\mathrm{b}}$ \\
\hline & Residual & .020 & 96 & .000 & & \\
\hline & Total & .034 & 97 & & & \\
\hline \multicolumn{7}{|c|}{ a. Dependent Variable: $R O A$} \\
\hline \multicolumn{7}{|c|}{ b. Predictors: (Constant), Leverage } \\
\hline \multicolumn{7}{|c|}{ Coefficients $^{\mathrm{a}}$} \\
\hline \multirow[t]{2}{*}{ Model } & & \multicolumn{2}{|c|}{ Unstandardized Coefficients } & $\begin{array}{l}\text { Standardized } \\
\text { Coefficients }\end{array}$ & $\mathrm{t}$ & Sig. \\
\hline & & $\mathrm{B}$ & Std. Error & Beta & & \\
\hline \multirow[t]{2}{*}{1} & (Constant) & .029 & .002 & & 15.725 & .000 \\
\hline & Leverage & -.104 & .013 & -.632 & -7.980 & .000 \\
\hline
\end{tabular}

a. Dependent Variable: $R O A$

Source: Authors compilation

\section{Effect of firm size on financial performance of DT-SACCOs in Kenya}

The results for the effect of firm size on the financial performance of DT-SACCOs in Kenya were assessed using the Pearson correlation coefficient, as shown in table 8 . The output indicates that firm size had a strong positive and significant relationship with the financial performance of DT-SACCOs in Kenya $(r=.604, n=98, p<0.05)$.

Table 8: Correlations between Firm Size and Financial Performance

\begin{tabular}{llll}
\hline \multirow{2}{*}{ ROA } & & ROA & Firm size \\
\cline { 2 - 4 } & Pearson Correlation & 1 & $.604^{* *}$ \\
\cline { 2 - 4 } & Sig. (2-tailed) & 98 & .000 \\
\cline { 2 - 4 } Firm size & $\mathrm{N}$ & $.604^{* *}$ & 98 \\
\cline { 2 - 4 } & Pearson Correlation & .000 & 1 \\
\cline { 2 - 4 } & Sig. (2-tailed) & 98 & 98 \\
\cline { 2 - 4 } & $\mathrm{N}$ & & \\
\hline \multirow{2}{*}{$* *$ Correlation is significant at the 0.01 level (2-tailed). }
\end{tabular}

Source: Authors compilation

The second objective was to assess the effect of firm size on the financial performance of DT-SACCOs in Kenya. The research hypothesis formulated from the specific research objective was;

$\mathbf{H}_{\mathbf{0}} \mathbf{2}$ Firms size does not significantly affect the financial performance of DT-SACCOs in Kenya.

To test the above hypothesis, linear regression was used to test the relationship between firm size and financial performance of DTSACCOs in Kenya. Path coefficients were used to determine the direction and strength while $\mathrm{T}=$ statistics provided information on the significance to the relationships. The results are presented in Table 9. 
The $\mathrm{R}^{2}$ for the regression model between firm size and financial performance of DT-SACCOs in Kenya was 0.365 meaning that firm size explains $36.5 \%$ variation in the financial performance of DT-SACCOs in Kenya while the remaining variation is explained by other factors. The regression model was a good fit, as indicated by a significant $F$ statistic $(F=55.150, p<0.05)$. The regression model obtained from the output was;

Eq. (4) $\mathrm{Yi}=0.135+0.006$ (firm size) $+\varepsilon$

The unstandardized regression coefficient for firm size was 0.006 . This indicates that a unit increase in the firm size would result in 0.006 increase in the financial performance of DT-SACCOs in Kenya. The t-statistic for the regression coefficient for firm size was significant at $5 \%$ level of significance $(\mathrm{T}=-7.426, \mathrm{p}<0.05)$ implying failing to confirm the null hypothesis. By these statistics, the study concludes that there is a significant positive relationship between firm size and financial performance of DT-SACCOs in Kenya.

Table 9: Effect of Firm Size on Financial Performance

\begin{tabular}{|c|c|c|c|c|c|c|}
\hline \multicolumn{7}{|c|}{ Model Summary } \\
\hline Model & $\mathrm{R}$ & R Square & & Adjusted R Square & \multicolumn{2}{|c|}{ Std. Error of the Estimate } \\
\hline 1 & $.604^{\mathrm{a}}$ & .365 & & .358 & .01493 & \\
\hline \multicolumn{7}{|c|}{ a. Predictors: (Constant), Firm size } \\
\hline \multicolumn{7}{|c|}{ ANOVA } \\
\hline \multicolumn{2}{|l|}{ Model } & Sum of Squares & $\mathrm{df}$ & Mean Square & $\mathrm{F}$ & Sig. \\
\hline \multirow[t]{3}{*}{1} & Regression & .012 & 1 & .012 & 55.150 & $.000^{\mathrm{b}}$ \\
\hline & Residual & .021 & 96 & .000 & & \\
\hline & Total & .034 & 97 & & & \\
\hline \multicolumn{7}{|c|}{ a. Dependent Variable: $R O A$} \\
\hline \multicolumn{7}{|c|}{ b. Predictors: (Constant), Firm size } \\
\hline \multicolumn{7}{|c|}{ Coefficients $^{a}$} \\
\hline \multirow[t]{2}{*}{ Model } & & \multicolumn{2}{|c|}{ Unstandardized Coefficients } & $\begin{array}{l}\text { Standardized } \\
\text { Coefficients }\end{array}$ & $\mathrm{t}$ & Sig. \\
\hline & & B & Std. Error & Beta & & \\
\hline \multirow[t]{2}{*}{1} & (Constant) & .135 & .016 & & 8.679 & .000 \\
\hline & Firm size & .006 & .001 & .604 & 7.426 & .000 \\
\hline
\end{tabular}

\section{Source: Authors compilation}

\section{Regression of Combined Leverage and Firm Size on Financial Performance}

The third objective was to determine the effect of combined capital structure determinants, leverage, and firm size on the financial performance of DT-SACCOs in Kenya. The research hypothesis formulated from the specific research objective was;

$\mathbf{H}_{\mathbf{0}} 3$ There is no significant effect of combined capital structure determinants leverage and firm size on the financial performance of DT-SACCOs in Kenya.

To test the above hypothesis, linear regression was used to test the combined effect of leverage and firm size on the financial performance of DT-SACCOs in Kenya. Path coefficients were used to determine the direction and strength while T=statistics provided information on the significance to the relationships. The results are presented in Table 10.

The $\mathrm{R}^{2}$ for the regression model for the combined effect of leverage and firm size on the financial performance of DT-SACCOs in Kenya was 0.584 meaning that financial leverage and firm size explain $58.4 \%$ variation in the financial performance of DT-SACCOs in Kenya while the remaining variation is explained by the error term. The regression model was a good fit, as indicated by a significant F-statistic $(\mathrm{F}=72.253, \mathrm{p}<0.05)$, implying failing to reject the null hypothesis. Based on these statistics, the study concludes that there is a significant combined effect of financial leverage and firm size on the financial performance of DT-SACCOs in Kenya.

The regression model obtained from the output was;

Eq. (5) $\mathrm{Y}_{\mathrm{i}}=0.106-0.084$ (leverage) +0.004 (firm size) $+\varepsilon$

The standardized regression coefficient for leverage was -0.504 . This indicates that a unit increase in the financial leverage would result in $50.4 \%$ decrease in the financial performance of DT-SACCOs in Kenya. The t-statistic for the regression coefficient for financial leverage was significant at $5 \%$ level of significance $(T=-7.382, \mathrm{p}<0.05)$.

The standardized regression coefficient for firm size was 0.420 . This indicates that a unit increase in the firm size would result in a $42 \%$ increase in the financial performance of DT-SACCOs in Kenya. The t-statistic for the regression coefficient for firm size was significant at $5 \%$ level of significance $(\mathrm{T}=6.155, \mathrm{p}<0.05)$. 
Table 10: Influence of Combined Leverage and Firm Size on Financial Performance

\begin{tabular}{|c|c|c|c|c|c|c|}
\hline \multicolumn{7}{|c|}{ Model Summary } \\
\hline Model & $\mathrm{R}$ & & & Adjusted R Square & \multicolumn{2}{|c|}{ Std. Error of the Estimate } \\
\hline 1 & $.764^{\mathrm{a}}$ & & & .576 & .01236 & \\
\hline \multicolumn{7}{|c|}{ a. Predictors: (Constant), Firmsize, Leverage } \\
\hline \multicolumn{7}{|c|}{ ANOVA $^{\mathrm{a}}$} \\
\hline Model & & Sum & df & Mean Square & $\mathrm{F}$ & Sig. \\
\hline \multirow[t]{3}{*}{1} & Regression & .022 & 2 & .011 & 72.253 & $.000^{\mathrm{b}}$ \\
\hline & Residual & .016 & 103 & .000 & & \\
\hline & Total & .038 & 105 & & & \\
\hline \multicolumn{7}{|c|}{ a. Dependent Variable: $R O A$} \\
\hline \multicolumn{7}{|c|}{ b. Predictors: (Constant), Firmsize, Leverage } \\
\hline \multicolumn{7}{|c|}{ Coefficients $^{\mathrm{a}}$} \\
\hline \multirow[t]{2}{*}{ Model } & & \multicolumn{2}{|c|}{ Unstandardized Coefficients } & $\begin{array}{l}\text { Standardized } \\
\text { Coefficients }\end{array}$ & $\mathrm{t}$ & Sig. \\
\hline & & $\mathrm{B}$ & Std. Error & Beta & & \\
\hline \multirow[t]{3}{*}{1} & (Constant) & .106 & .013 & & 8.364 & .000 \\
\hline & Leverage & -.084 & .011 & -.504 & -7.382 & .000 \\
\hline & Firmsize & .004 & .001 & .420 & 6.155 & .000 \\
\hline
\end{tabular}

a. Dependent Variable: $R O A$

Source: Authors compilation

\section{Discussion of Results}

\section{Effect of leverage on financial performance of DT-SACCOs in Kenya}

Inferential regression results show a significant negative relationship between leverage and financial performance. The higher the leverage of the DT-SACCO, the lower the financial performance, and the lower the leverage, the higher the financial performance. Hence the rejection of the null hypothesis. This is critical for the DT-SACCOs given that the study indicated that financial leverage as an only determinant of capital structure influenced $39.9 \%$ of financial performance and a unit increase in financial leverage would result in $10.4 \%$ decrease in the financial performance of the institution. Leverage comes at a cost to the DT-SACCO, and when this is not able to be covered by increased charges to members, to remain affordable would result in declining financial performance. The descriptive statistics further support this finding showing the lowest ranking in terms of capital structure determinant and additionally impact on financial performance.

Outcomes of the study give evidence in support pecking order theory. The Pecking order theory advocates for financing decisions that cause the least difficulty to management, moving from safer to riskier funding, thus giving an advantage to internal financing as compared to external financing. The findings in this study are consistent with works of, Gweyi and Karanja (2014) and Mwatu \& Abdul (2018), who found a negative and significant relationship between leverage and performance.

\section{Effect of firm size on financial performance of DT-SACCOs in Kenya}

Inferential regression results show a significant positive relationship between firm size and financial performance. The study indicated that firm size as an only determinant of capital structure influenced $36.5 \%$ of financial performance and a unit increase in firm size would result in $0.6 \%$ increase in the financial performance of the institution. Hence the rejection of the null hypothesis. The significance of firm size on performance indicates the large DT-SACCOs earn high return compared to smaller ones, hence can have high retained earnings impacting positively on capital.

According to a study by Orser, Hogarth-Scott, and Riding (2000), Canadian firms using changes in gross revenue to reflect performance found a positive effect for a firm's size supporting the arguments that size reflects greater diversification, economies of scale production, greater access to new technology and cheaper sources of funds in line with the trade-off theory. The study of Mwizarubi, Kumar, Mnzala, and Prusty (2016) on SACCOs in Tanzania found a negative relationship between size and performance contrary to the results of this study, they cited, management incompetence and misuse of resources as the SACCOS grow, nonadherence to corporate governance principles and mechanisms as a possible reason for their findings.

\section{Conclusions}

The objective of the study was to determine how leverage and firm size affect the financial performance of DT-SACCOs in Kenya; results showed leverage having a significant negative effect on financial performance. This implies that increased debt position hurts the bottom line for DT-SACCOs hence emphasizes the importance of internally generated funds to run operations in line with pecking order theory and conformity with the recommendation of cooperative principles. However, given the changing dynamics of DTSACCO operations, it would also mean expanding their source of external funds and move away from the more traditional and 
expensive source they have of commercial banks loans. Thus, there is a need to consider alternative sourcing of external funds just as banks are doing from sources such as IFC, EDB.

Further, there is a need for DT-SACCOs to consider the use of products such as corporate bonds to raise funds, especially for capitalintensive projects. The regulator prescribes for a minimum $2 \%$ margin on loans lent to members from borrowed funds however this has been a difficult aspect to implement for DT-SACCOs as it would push up the cost of their facilities negating their attraction as affordable credit providers. Policy guidelines are required to facilitate the creation of an inter SACCO market similar to the interbank market that will allow borrowing amongst DT-SACCOs at affordable rates. All of this will be to reduce the cost of debt. Finally, ensure that any borrowed funds are put into revenue-generating activities.

The second objective of the study was to find out how firm size influences the financial performance of DT-SACCOs in Kenya, and results showed that firm size has a significant positive relationship with financial performance. To have consistent and sustainable growth achieving critical mass is important for the improved financial performance of DT-SACCOs. Firm's size for DT-SACCOs is driven by a growing loan book which is driven by product innovation and growing membership.

\section{References}

Ademba (2013). Speech for the Chief Executive Officer, SASRA during the SACCO leaders Forum, held at KICC on $26^{\text {th }}$ August 2013.

Amedeo De Cesari, Susanne Espenlaub, Arif Khurshed \& Michael Simkovic. (2010) The effects of Ownership and Stock Liquidity on the Timing of Repurchase Transactions. Prentice-Hall

Andrews A.M. (2015). Survey of Co-operative Capital. Madison, Filene Research Institute

Anyanzwa, J. (2018 Wednesday 26). Harambee Sacco to auction houses and land to boost cash flows. The East

African Newspaper.

Bauer, P. (2004). Determinants of Capital Structure: Empirical Evidence from the Czech Republic. Czech Journal of Economics and Finance (Finance a uver), Charles University Prague, Faculty of Social $\quad$ Sciences, Vol. 54(1-2), pages 2-21.

Chaddad, F.H. \& Cook, M.L. (2004).Understanding new cooperative models: ownership-control rights typology,Review of Agricultural Economics,Vol.26 No. 3, pp. 348-360.https:// doi.org/10.2307/3700806

Creswell, J. W. (2013). Research design: Qualitative, quantitative, and mixed methods approach. Sage Publications, Incorporated

Downing, M., Volk, T.A. \& Schmidt, D.A. (2005).Development of new generation cooperatives in agriculture for renewable energy research, development, and demonstration projects. Biomass and Bioenergy, Vol. 28 No. 5, pp. 425-434. https://doi.org/10.1016/j.biombioe.2004.09.004

Fama, E. F., \& K. R. French. 2002. Testing trade-off and pecking order predictions about dividends and debt. The Review of Financial Studies 15(1), (spring): pp.1-33. https://doi.org/10.1093/rfs/15.1.1

Financial Sector Regulator Forum. (2017). The Kenya Financial Sector Stability Report. September 2017. Issue no 8 pp 33-34

González, Victor \& González, Francisco. (2012). Firm size and capital structure: Evidence using dynamic panel data. Documentos de Trabajo FUNCAS, No. 340, 2007. 44. https://doi.org 10.1080/00036846.2011.595690

Gweyi, O, \& Karanja, J. (2014). Effect of Financial Leverage on Financial Performance of Deposit Taking Savings and Credit CoOperatives in Kenya. International Journal of Academic Research in Accounting and Management Science Vol. 4, No.2: April 2014, pp176-184. http://dx.doi.org/10.6007/IJARAFMS/v4-i2/838

International Cooperative Alliance (2016). Cooperative Identity, Values \& principles: Available at https://www.ica.coop/en/cooperatives/cooperative-identity.

Kothari, C.R. (2004). Research Methodology: Methods and techniques. New Delhi. New Age International (P) Ltd publishers

Kraus, A.; Litzenberger, R.H. (1973). A State-Preference Model of Optimal Financial Leverage. Journal of Finance. 28: 911-922. https://doi.org/10.1111/j.1540-6261.1973.tb01415.x

Kühnhausen F., \& Stieber H.W (2014): Determinants of Capital Structure in Non-financial Companies Munich Discussion Paper No. 2014-38 Department of Economics University of Munich. Online at http://epub.ub.uni-muenchen.de/21167/

Labie, M. \& Périlleux, A. (2008): Corporate Governance in Microfinance: Credit Unions, Working Paper CEB: No. 08-003.

Marete, G. (2016, April 8). Bandari Sacco officials in Kshs 5m blame game. The Daily Nation Newspaper.

Milcah \& Muturi (2016). Financial factors are affecting the performance of deposit-taking savings and credit co-operative societies in Kenya: a case of Kiambu County. International Journal of Social Science \& Information technology, Vol II Issue IX, October 2016

Modigliani, F., and Miller, M. (1958). The Cost of capital corporation Finance and the theory of Investment. American Economic Review, June 1958, 261-97. https://doi.org/ http://dx.doi.org/10.1080/17446540802345448

Modigliani, F. F. \& Miller, M. H., 1963.-Corporation income taxes and the cost of capital: a correction, American Economic Review, 53(3), 433-443.

Mohammed (2013). Speech by the Honourable Cabinet Secretary, Ministry of Industrialization and Enterprise Development during the SASRA Sacco Leaders Forum, at KICC on 26th August

Mugenda, A.G. (2008), Social Science Research: Theory and principles. Nairobi. Kijabe printing press.

Munaita, P. (2018, April 17). Metropolitan Sacco probed over cash woes. The Daily Nation Newspaper.

Mvula, R. (2013). Report on Common issues affecting the performance of SACCO. Presented in Malawi, 8th August 2013. 
Mwatu, M.D., Abdul, F. (2018). Capital Structure and the Financial Performance of Deposit-Taking Savings and Credit Cooperatives Societies in Kenya. International Journal of Current Aspects in Finance (IJCAF), Volume IV, Issue II, May 2018, PP 71-88

Mwizarubi, M., Kumar, R., Mnzava, B \& Prusty, S. (2016). Financing Alternatives for SACCOs and their Impact on Financial Performance: Evidence from Tanzania. The Researcher- International Journal of Management Humanities and Social Sciences July-Dec 2016, 1(2) pp. 33-45

Myers, S. C. (1984) Finance Theory and Financial Strategy. Interfaces, Vol. 14, no. 1, pp.126-137. https://doi.org/10.1287/inte.14.1.126

Myers and Majluf N.S. (1984). Corporate financing and investment decisions when firms have information those investors do not have, The Journal of Financial Economics. Vol.13, Issue 2, pp.187-221. https://doi.org/10.1016/0304-405X(84)90023-0

Njeri, M.M.K, and Kagiri. A.W (2015). Effect of Capital Structure on Financial Performance of Banking Institutions Listed in Nairobi Securities Exchange. International Journal of Science and Research. Vol. 4 Issue 7

Nunnally, J. C. (1978). Assessment of Reliability. In: Psychometric Theory (2nd Ed.). NewYork: McGraw-Hill. Pages 245-246

Orser BJ, Hogarth-Scott S \& Riding AL 2000 Performance, Firm Size, and Management Problem-Solving. Journal of Small Business Management 38, 44258

Polit, D \& Hungler, B.P. (1999). Nursing research: Principles and methods. 6th edition. Philadelphia: Lippincott

Poulsen, A. (2008). Corporate financial structure. Indianapolis: Library of Economics and Liberty.

Rajan, R., and Zingales. L. (1995). What do we know about capital structure? Some evidence from international data. Journal of Finance.50.1421-1460. https://doi.org/10.1111/j.1540-6261.1995.tb05184.x

Sacco Societies Regulatory Authority. (2017). The Sacco supervision annual report 2017.Nairobi. SASRA

Shawal, M.Capital Structure of a firm; Meaning and its determinants: Available at https://www.yourarticleliabrary.com

Sheikh, NA, Wang Z. (2011). Determinants of capital structure: An empirical study of firms in the manufacturing industry of Pakistan. Managerial Finance, 37, 2, 117-133. https://doi.org/ http://dx.doi.org/10.1108/03074351111103668

Shubita, M.F, and Alsawalhah, J.M. (2012). The Relationship between Capital Structure Profitability. International Journal of Business and Social Science Vol 3 No.16

Singh, P., Kumar, B., (2008), Trade-Off Theory, or Pecking Order Theory: What Explains the Behaviour of the Indian Firms? Available at http://ssrn.com/abstract $=1263226$.

Taiwo, A.M. (2012). An empirical analysis of capital structure on firm's performance in Nigeria. International Journal of Advances in Management and Economics, 1(5), 116-124.

Titman, S. \&Wessels, R. 1988.The Determinants of Capital Structure Choice. Journal of Finance, Vol. 43, no. 1, p. 1. https://doi.org/10.1111/j.1540-6261.1988.tb02585.x

Wanzala, O. (2019, February 28). Laxity in Bank purchase leaves teachers with 2 billion mess. Daily Nation.

Wasike, J. (2012). Corporate governance practices and performance at Elimu Sacco in Kenya, Unpublished MBA project, University of Nairobi

World Council of Credit Unions (2005). 2005 Statistical Report. Available: http://www.woccu.org/documents/2005_Stat_Report

World Council of Credit Unions (2012). 2012 Statistical Report. Available: http://www.woccu.org/documents/2012_Stat_Report

World Council of Credit Unions (2015). 2015 Statistical Report. Available: http://www.woccu.org/documents/2015_Stat_Report

Xhaferi, S., and Xhaferi, B. (2015). Alternative Theories of Capital Structure. European Scientific Journal, Vol 11. No 7 pp 327-343

Yamane, Taro. (1967): Statistics: An Introductory Analysis, 2nd Ed., New York: Harper and Row. 